ÖKOLOGISCHE PERSPEKTIVEN FÜR WISSENSCHAFT UND GESELLSCHAFT ECOLOGICAL PERSPECTIVES FOR SCIENCE AND SOCIETY $2 \mid 2011$


- NUCLEAR POWER AND ENERGY SECURITY - PHOSPHORUS RECOVERY FROM BONES AFTER BSE - UMWELTGESCHICHTE IN DER SCHULE 


\title{
The Trade-Off between Phosphorus Recycling and Health Protection during the BSE Crisis in Switzerland
}

\author{
A "Disposal Dilemma"
}

Heinz Lamprecht, Daniel J. Lang,

Claudia R. Binder, Roland W. Scholz
Phosphorus is a limited resource; its scarcity may affect food security. It is therefore important to recycle phosphorus in agriculture. Due to the BSE crisis, Switzerland banned the use of meat and bone meal, which contains high amounts of phosphorus, for animal feed and fertilizers. Significant amounts of phosphorus were lost from the phosphorus cycle as health concerns were prioritized over phosphorus recycling.

\section{The Trade-Off between Phosphorus Recycling and Health Protection during the BSE Crisis in Switzerland. A "Disposal Dilemma" \\ GAIA 20/2 (2011): 112-121}

\begin{abstract}
Phosphorus $(P)$ is an essential, finite resource whose geological, economic, and geopolitical accessibility may become critical in the future. Because P losses from agriculture, sewage and waste have serious environmental impacts such as eutrophication, it would be desirable to close $\mathrm{P}$ cycles. However, there may arise dilemmas due to trade-offs with other issues. For instance, recycling of animal bones - containing relatively high amounts of $\mathrm{P}$ - was prohibited in Switzerland after the BSE crisis (1989 to 2000) due to perceived health risks. Our analysis indicates that the greatest potentials for closing the $\mathrm{P}$ cycle in Switzerland are to reduce $\mathrm{P}$ losses in agriculture and to increase $\mathrm{P}$ recovery from sewage and waste. Whereas in agriculture significant improvements have been made, the disposal dilemma of animal bones led to diminishing amounts of $\mathrm{P}$ being recycled from waste. Based on their risk perception, the involved stakeholders prioritized preventing potential harm to (human) health over maximizing P recycling.
\end{abstract}

\section{Keywords}

agent analysis, animal bones, bovine spongiform encephalopathy (BSE), disposal dilemma, material flow analysis, non-renewable resources, phosphorus, resource management, Switzerland

\section{The Phosphorus Cycle}

Phosphorus $(\mathrm{P})$ is a finite resource and an essential element of life in all plants and animals (see box). From waste or from water sediments, $\mathrm{P}$ can only be recovered with high technological efforts. Worldwide, about 160 million tonnes of phosphate rock are produced annually (USGS 2010). P from raw phosphorus deposits is primarily used for fertilizers (80 percent) and animal feed (five percent). The remaining 15 percent are put to industrial use (see, e. g., Heffer et al. 2006, quoted in Syers et al. 2008).

In recent years, a fierce debate has broken out regarding the magnitude of $\mathrm{P}$ reserves. For a long time, the static reserves of $P$ were estimated to be between 90 and 100 years' worth (Notholt et al. 1989, USGS 2010). However, analyses by Cordell et al. (2009) suggest that reserves could be exhausted in 50 to 100 years and that a "phosphorus peak" could be reached as early as 2035. In contrast, the International Fertilizer Development Center (Van Kauwenbergh 2010) has published a survey raising the estimate of P availability to 300 to 400 years. All current estimates can be criticized regarding their methods (Schröder et al. 2010, Vaccari and Strand 2010). Given the scarce data on P resources and reserves as well as P demand dynamics, no reliable joint estimate from the various scientific and economic actors is expected in the short term, and a thorough investigation of the P supply chain seems necessary. However, according to Ayres (2007) - given the current agricultural system and consumption patterns - a future phosphorus shortage seems to be likely, at least in the long run.
Contact: Heinz Lamprecht, Dipl.-Natw. ETH | BMG Engineering AG | Bereich Chemikaliensicherheit | Schlieren | Switzerland | E-Mail: heinz.lamprecht@alumni.ethz.ch

Prof. Dr. Daniel J. Lang (corresponding author) | ETH Zurich | Institute for Environmental Decisions | Natural and Social Science Interface | Zurich | Switzerland and

(c) 2011 H. Lamprecht et al.; licensee oekom verlag. This is an Open Access article distributed under the terms of the Creative Commons Attribution License (http://creativecommons. org/licenses/by/3.0), which permits unrestricted use, distribution, and reproduction in any medium, provided the original work is properly cited.
Leuphana University Lüneburg | Scharnhorststr. 1 | 21335 Lüneburg | Germany | Tel.: +4941316771678 | E-Mail: daniel.lang@leuphana.de

Prof. Dr. Claudia R. Binder | ETH Zurich | Institute for Environmental Decisions | Natural and Social Science Interface | Zurich | Switzerland and University of Graz | Institute for Systems Science, Innovation and Sustainability Research | Graz | Austria | E-Mail: claudia.binder@uni-graz.at

Prof. Dr. Roland W. Scholz | ETH Zurich | Institute for Environmental Decisions | Natural and Social Science Interface | Zurich | Switzerland | E-Mail: roland.scholz@env.ethz.ch 
The limited availability of $\mathrm{P}$, the environmental impacts of its mining (see, e. g., Wilsenach et al. 2003) and the excessive release of the element (e.g., water eutrophication, see Smil 2000) have led to demands to close the anthropogenic P cycle as far as possible (see, e.g., Jönsson 2002, Schuh 2005, Schenk 2011).

In contrast to this idea, animal bone processing, which contributed to closing the P cycle, was abandoned in Switzerland during the $\mathrm{BSE}^{1}$ crisis for health security reasons. This trade-off between the objectives of a closed resource cycle and health security can be described as a "disposal dilemma".

\section{History of Animal Bone Disposal in Switzerland}

Compared with other types of biomass, animal bones contain high amounts of phosphorus (table 1, p. 114) and were once a desirable raw material offering a diverse range of application options (e.g., as the basic raw material in bone glue). Until a few years ago, the predominant uses of animal bones in Switzerland were for animal feed (as meat and bone meal, MBM) and for gelatin extraction, which brought the highest returns. ${ }^{2}$ However, after the first case of BSE was diagnosed in Switzerland in 1990, the authorities gradually tightened the regulations on the use of animal by-products. Finally, in 2001, the use of MBM for animal feed as well as fertilizers was banned (DüV 2001, DüBV 2001). The market for gelatin grain collapsed because of a lack of acceptance.

At that time, around 85 to 90 percent of all waste bones from meat processing in Switzerland (50,000 to 60,000 t/a, which makes about ten kilograms per adult citizen every year) were processed by the company Geistlich Agrasana AG in Schlieren, Canton of Zurich. The ban on MBM confronted this company with the challenge of quickly finding new ways to economically deal with the basic raw material (bones) of their once valued products. At the same time, the authorities in charge were required to introduce a safe disposal method. Initially, this was mainly achieved by incinerating the bones along with other waste in coalpowered furnaces at German power stations, while animal meal from meat offal was incinerated at cement and waste incineration plants. The phosphorus ended up either in the ashes, making its recovery difficult, or mixed into cement with other minerals, making it permanently unusable as a nutrient.

\section{Are Bones Relevant to Switzerland's Phosphorus Balance?}

The bone disposal dilemma raises three questions:

1. What role does bone disposal play in the total flow of phosphorus (phosphorus balance) in Switzerland?

2. How has the flow of phosphorus changed during the BSE crisis period (between 1989 and 2002)?

3. What was the societal background of the development?
Phosphorus $(\mathrm{P})$ is a chemical element and thus cannot be produced artificially. P compounds can be found in large quantities in the biomass of all living creatures (table 1, p. 114), where they fulfil vital functions. $P$ is often the limiting factor for primary production. Among others, it is an energy store and source in the form of adenosine diphosphate (ADP) and adenosine triphosphate (ATP). It is also found in genetic material, proteins, and enzymes, as well as in sugar phosphates and phospholipids. Phosphates are important buffer substances in cells and in blood, and $P$, especially in the form of the mineral hydroxyapatite, is one of the main components of bones and teeth (Scheunert and Trautman 1987). Traces of P can be found throughout nature, and small quantities of it are released when rock or soil particles are exposed to the elements. $P$ is highly reactive and therefore is not found as a free element in nature. Rather highly concentrated natural deposits of raw $\mathrm{P}$ compounds are mainly minerals in phosphate rock. Significant deposits are found in Morocco and the Western Sahara, Russia (Kola), South Africa, the USA, Jordan, and China. More than three-fifths of the $\mathrm{P}$ deposits mined are from marine sediment. More than one-fifth is of volcanic origin, and a small part of the remainder is Guano, i. e., fossilized bird excrement (FOAG 2002). The most important phosphate mineral is apatite, $\mathrm{Ca}_{10} \mathrm{~F}_{2}\left(\mathrm{PO}_{4}\right)_{6}$ (Patyk and Reinhardt 1997).

\section{$P$ in the nutrient cycle}

Harvesting crops removes more $\mathrm{P}$ from the soil than is released by the weathering of soil particles and bedrock. Unless this is balanced out - in the long run - the soil becomes poor in P. Thus, similar amounts of $\mathrm{P}$ have to be ploughed back into the soil as are removed with each harvest. However, a significant fraction of $P$ inputs into the soil is fixed to particles, which prevents bioavailability.

Material flow analysis (MFA) is a method used to analyze, measure, and interpret metabolic processes. It is a scientific procedure, which quantifies material or energy flows in a defined space over a certain period of time (system boundaries; see Brunner and Rechberger 2004, Baccini and Bader 1996). An MFA system usually consists of processes as well as flows. Processes comprise transformation, transport, storage, and use of materials and goods (Baccini and Bader 1996). Flows signify the transfer of goods or materials (in their pure form or as components of goods) from a start to an end process.

Global phosphorus flows have been analyzed by various researchers (see, e.g., Liu et al. 2008). Because of P's key role in agriculture (Smil 2000), however, most of the existing material $\mathrm{P}$ balances focused on the agriculture system and were restricted to national levels (see, e.g., Spiess and Plüss 1999). In this article, the spatial system investigated is Switzerland and the phosphorus balances are calculated for one year. The system contains six processes (table 2, p. 115) as well as eight import, four export, and 23 internal flows. In order to analyze the effects of the ban

\footnotetext{
1 BSE (bovine spongiform encephalopathy), also called "mad cow disease", is a fatal brain disease caused by prions that may be transferred to humans and potentially cause variant Creutzfeldt-Jakob disease (vCJD).

2 Stated by Andreas Geistlich, Geistlich Agrasana AG, in December 2003.
} 
TABLE 1: Phosphorus contents of selected goods.

\begin{tabular}{|c|c|}
\hline $\begin{array}{l}\text { description } \\
\text { (DS: dry substance, FS: fresh substance) }\end{array}$ & $\begin{array}{l}\text { rus content } \\
\text { eercentage) }\end{array}$ \\
\hline bone shred, Geistlich Agrasana AG, FS a & $9.0-11.0$ \\
\hline bone meal, Geistlich Agrasana AG, FS b & 7.7 \\
\hline meat meal, Geistlich Agrasana AG, FS ${ }^{c}$ & 5.1 \\
\hline fresh bones, Geistlich Agrasana AG, 2001-2002, FS ${ }^{d}$ & 3.0 \\
\hline sewage sludge, DS e & 2.5 \\
\hline animal waste from meat processing, $2002, \mathrm{FS}^{f}$ & 1.1 \\
\hline soy beans, dried seeds (91.5\% DS)g & 0.650 \\
\hline cheese: Tilsit cheese, FS ${ }^{h}$ & 0.500 \\
\hline cereals: feed wheat, grains, FS (87\% DS) ${ }^{i}$ & 0.380 \\
\hline compost, DSe & 0.301 \\
\hline beef, FS (24.7\% DS) g & 0.237 \\
\hline pork, lean meat without fat, FS ${ }^{h}$ & 0.204 \\
\hline waste, Weinfelden, St. Gallen, DS (water content $22 \%$ ), $2003^{i}$ & 0.092 \\
\hline cow milk, raw, FS h & 0.092 \\
\hline potatoes, raw, freshly harvested, FS ${ }^{h}$ & 0.050 \\
\hline vegetables, Swiss production 1998, FS ${ }^{k}$ & 0.039 \\
\hline Cola drinks, $\mathrm{FS}^{\mathrm{h}}$ & 0.014 \\
\hline apple, unpeeled, raw, $\mathrm{FS}^{\mathrm{h}}$ & 0.010 \\
\hline
\end{tabular}

a technical fact sheet Bone Shred, 11.04.2001, Geistlich Agrasana AG | b technical fact sheet Bone Meal, 11.04.2001, Geistlich Agrasana AG I c technical fact sheet Meat Meal, 11.04.2001, Geistlich Agrasana AG | d calculations Roman Müller, Geistlich Agrasana AG, 08.11.2003 | e Spiess and Plüss (1999, p. 41) | f own calculations (without carcasses) | g DLG (1973) | h Elmadfa(1988/1989) | Wirz (2002, p.644) I j FOEN (2003) I k Elmadfa (1988/1989), Swissveg (2003)

on the use of MBM in animal feeds and fertilizers, two MFAs were calculated for the years 1989 (the situation before BSE) and 2002, respectively. Data sources were literature and interviews with experts from companies and authorities. In a few cases, we made own estimates. Additionally, error estimations and calculations were carried out using the Gaussian approach of uncertainty assessment (Baccini and Bader 1996, for details on data sources, calculations, validation, and error estimations see Lamprecht 2004).

In only considering Switzerland's national P balance, the system boundaries chosen are rather narrow. P flows cross borders worldwide, predominantly in the form of fertilizers and agricultural exports/imports. P flows often go from developing countries to industrialized nations. For this reason, considerations on resource management of P should include an in-depth analysis of import-export flows in order to take into account effects in faroff areas (see, e. g., Würtenberger et al. 2006). However, with regard to the main objective of this article - the analysis of the dilemma concerning bone disposal - the national level seems to be an appropriate examination unit.

\section{Main Phosphorus Flows in 2002}

Figure 1 (p. 117) shows Switzerland's most important phosphorus flows in the years 1989 and 2002. In 2002, the two largest flows were between the processes of crop production and livestock rearing, i. e., plant-based animal feed $(22,500 \mathrm{t} \mathrm{P} / \mathrm{a})^{3}$ and animal excreta $(20,500 \mathrm{t} \mathrm{P} / \mathrm{a})$. Together, these flows constituted a nearly closed cycle within agriculture. The quantity of imported phosphorus (about 17,000 t P/a) was four to five times larger than the amount flowing out of the system (table 3, p. 116). Thus, P stocks in Switzerland were increasing. Most phosphorus was imported in the form of animal feed $(6,500 \mathrm{tP} / \mathrm{a})$ and mineral fertilizer $(6,400 \mathrm{t} \mathrm{P} / \mathrm{a})$. In crop production, input was about $32,000 \mathrm{t} \mathrm{P} / \mathrm{a}$ (plus weathering), and the amount of $\mathrm{P}$ leaving the process in the form of food and losses (e. g., erosion) was about 29,500 t P/a, leading to a yearly stock increase of about 4,000 t. ${ }^{4}$ Relevant flows also included livestock produced $(4,500 \mathrm{tP} / \mathrm{a})$, dairy products, eggs, and wool (3,200 t P/a), as well as plant products $(2,700 \mathrm{t} \mathrm{P} / \mathrm{a})$. In meat processing of the $4,500 \mathrm{t} \mathrm{P} / \mathrm{a}, 850$ were meat for consumption, whereas the rest were by-products, which ended up in sewage and waste management. In this latter flow, the share of bones is about 50 percent. There is a balance deviation of slightly more than 20 percent in the meat processing process $(1,100$ $\mathrm{t} \mathrm{P} / \mathrm{a}$ ), due to the diverse and unknown $\mathrm{P}$ concentrations in flows of individual goods.

The total input into the sewage and waste management process was $13,000 \mathrm{tP} / \mathrm{a}$ - whereof 7,000 were from sewage, 3,500 from waste and separately collected organic waste, 2,600 from animal carcass. Thus, animal carcasses accounted for about ten percent of the $P$ flow into the sewage and waste management process. From sewage and waste management, only about 4,000 t P/a (30 percent) were brought back into crop production, about 8,000 were lost from the cycle to landfill sites. The export of $\mathrm{P}$ in water bodies, e. g., the Rhine River as the largest P net exporter in Switzerland, amounted to about 2,700 t/a, which corresponded to about 15 percent of the entire $P$ imported.

\section{Changes Between 1989 and 2002}

Two main differences between the two periods can be observed:

1. Mineral fertilizer imports decreased by about 63 percent, from $17,400 \mathrm{t}$ P/a in 1989 to $6,400 \mathrm{tP} / \mathrm{a}$ in 2002. Concomitantly, the stock increase in crop production (pedosphere) was reduced from over 18,000 to around 4,000 t P/a. This is inter alia related to the direct payments (subsidies) in agriculture which since 1999 - are based on stringent proof of ecological performance (including balanced use of fertilizers). In line with this, a tendency towards more efficient $P$ use is widespread in the developed world (IFADATA 2011).

2. In 1989, animal by-products were mainly used as animal feed, and, to a smaller extent, as fertilizer. Following the 2001 ban on MBM in farm animal feed and fertilizers, animal by-products were removed from the nutrient cycle permanently. As a result, the P load in the flow of "animal feed of animal origin" dropped by 98 percent, from 2,700 to $55 \mathrm{t} / \mathrm{a}$, and the flow of "fertilizers of animal origin" does no longer exist.

$3 \mathrm{tP} / \mathrm{a}$ : tonnes of phosphorus per year.

4 It should be noted that the phosphorus cycle in the pedosphere is very complex and that a certain amount of $\mathrm{P}$ is present in a form not suitable for plants (see, e. g., Sims and Vadas 2005). This P cannot be considered as unused but usable stock. 
TABLE 2: Definitions of the processes studied in the phosphorus material flow analysis for Switzerland (figure 1, p. 117).

\begin{tabular}{|c|c|}
\hline description & definition \\
\hline crop production & land used for growing crops using the top layer of soil (agriculture and para-agriculture ${ }^{\mathrm{a}}$ ) \\
\hline livestock rearing & rearing livestock for agricultural purposes (agriculture) \\
\hline meat processing & $\begin{array}{l}\text { meat processing companies (large abattoirs, large processing plants, butchers' shops) and home slaughtering by } \\
\text { individuals; covers the activities of slaughtering, quartering, production, storage and sales }\end{array}$ \\
\hline consumption & includes households, industry and business, excludes meat processing \\
\hline sewage and waste management & sewage treatment and waste disposal system, including distribution processes for buyers of animal by-products \\
\hline $\begin{array}{l}\text { other (internal system) geosphere, } \\
\text { including landfills }\end{array}$ & $\begin{array}{l}\text { geosphere, including landfills, excluding the other processes in the anthroposphere; further subdivided into } \\
\text { lithosphere, hydrosphere, biosphere and landfill sites }\end{array}$ \\
\hline
\end{tabular}

a We define para-agriculture as cultivation or management of non-agricultural areas covered with vegetation where nutrients are supplied or biomass is removed by human influence, e. g., cultivation of private gardens, public green areas (parks, cemeteries), recreational areas (sports facilities, golf courses, camping grounds), as well as green spaces along streets, railways, and airports.

\section{Bone Disposal: A Considerable Loss from the Cycle?}

Quantitatively, bones do not represent the largest source of potential improvements for the national P cycle, although their P content is by no means negligible. The amount of 1,500 $\mathrm{tP} / \mathrm{a}$ in the bones supplied to the Geistlich company that were no longer used after the BSE crisis corresponded to nine percent of $\mathrm{P}$ imports in 2002. All by-products from meat production $(2,600 \mathrm{tP} / \mathrm{a})$ equated to 15 percent (figure 2, p. 118), whereas total P losses from agriculture and meat processing (including unused stock) are $8,900 \mathrm{t} \mathrm{P} / \mathrm{a}$, corresponding to about half of the known P imports. Thus, changing the agricultural production systems - minimizing P losses from agricultural soils, minimizing accumulation of $\mathrm{P}$ which is not plant available, minimizing meat consumption - would be an efficient way of reducing P losses from the cycle.

From an end-of-pipe perspective, the P losses via sewage and waste management in 2002 were in the same magnitude as the total loss from agriculture and meat processing. Sewage and waste management could therefore make a relevant - and presumably feasible - contribution to closing the P cycle in Switzerland (Binder et al. 2009).

From a purely material point of view, there are several reasons supporting the recycling of animal bones:

- The animal waste P load in this flow still represents a significant amount in the Swiss P balance (figure 1, p. 117).

- Bones have a high concentration of phosphorus, compared to that in other biomass (table 1).

- Animal waste must undergo a special disposal process for hygienic reasons. Consequently, it remains necessary for bones to be collected separately and processed centrally.

- In contrast to other waste fertilizers, bones are relatively unproblematic in terms of harmful toxicants. For instance, they contain significantly less heavy metals than geogenic raw phosphate (Smil 2000).

However, plant uptake of $\mathrm{P}$ from MBM is rather slow and is hindered in high-pH soils (see, e. g., Jeng et al. 2006, Ylivainio et al. 2008), which may ask for further processing. Besides, if one wants to completely eliminate the risk of possible micro-pollutants from pharmaceutical products, MBM must be incinerated. The ashes can be used as fertilizers effectively only after solublilization of the P contained (Schnug et al. 2011).

\section{Societal Background of the Disposal Dilemma}

Even if the removal of bones from the phosphorus cycle is not of utmost importance quantitatively, we consider it worth investigating the backgrounds of the disposal dilemma: What (societal) structures and processes have hindered or rendered it more difficult to close the cycle with respect to bone disposal? Can any specific conclusions be reached regarding other relevant examples?

Decision-making processes in resource management are often influenced by many actors and different material, economic, technological, and social criteria need to be considered (see Lang et al. 2006). To understand the causes of the disposal dilemma and to develop action options, we combined the results of the MFA with agent analyses. We adapted the structural agent analysis (SAA) approach described by Binder (2007) and Binder et al. (2004). The data were gathered from interviews with experts from the waste management sector, local authorities, and science. The interviewees named involved actors, their relevance, and the kinds of relationships between them. The experts' statements were consistent and were merged into an overall picture. Interactions between actors were identified at five different levels: flow of goods, flow of money, flow of information, regulations, and acceptance.

\section{Societal Developments during the BSE Crisis}

Any disposal solution must not only be ecologically meaningful and economically viable, but also be accepted by society. In line with this, our agent analysis revealed two closely related societal control mechanisms that contributed to the observed developments during the BSE crisis:

1. legal actions (regulations) by authorities (laws, decrees, provisions),

2. acceptance problems on the part of retailers and end consumers. 
TABLE 3: Phosphorus balance for Switzerland (tonnes of phosphorus per year $[\mathrm{tP} / \mathrm{a}]$, rounded values).

\begin{tabular}{|c|c|c|c|c|}
\hline & \multirow{2}{*}{$\begin{array}{c}1989 \\
\text { (t P/a) }\end{array}$} & \multirow{2}{*}{$\begin{array}{c}2002 \\
\text { (t P/a) }\end{array}$} & \multicolumn{2}{|c|}{ change } \\
\hline & & & (t P/a) & (\%) \\
\hline input & 28,000 & 17,000 & $-11,000$ & -38 \\
\hline mineral fertilizer (imports) & 17,400 & 6,400 & $-11,000$ & -63 \\
\hline - feed (imports) & 6,500 & 6,500 & - & - \\
\hline - other food products (imports) a & 1,900 & 2,400 & +500 & +28 \\
\hline - dishwasher detergent & 1,400 & 1,300 & -100 & -11 \\
\hline - pet food (net imports) & 300 & 300 & - & - \\
\hline - meat (net imports) & 220 & 240 & +20 & +13 \\
\hline - seeds (net imports) & 31 & 24 & -8 & -25 \\
\hline - net immigration of human population & 18 & 15 & -3 & -19 \\
\hline - live animals (net imports) & 6 & 34 & +28 & +467 \\
\hline - other net imports of goods ${ }^{b}$ & ? & ? & $?$ & ? \\
\hline output & 5,200 & 4,100 & $-1,200$ & -22 \\
\hline - surface water flow & 3,700 & 2,700 & $-1,000$ & -27 \\
\hline - other food products (exports) ${ }^{c}$ & 700 & 1,100 & +400 & +55 \\
\hline - raw animal products (exports) & 510 & - & -510 & -100 \\
\hline - pig bones (exports) & 300 & 250 & -50 & -17 \\
\hline storage increase & 24,500 & 12,000 & $-12,500$ & -51 \\
\hline - landfill & 6,500 & 8,000 & $+1,500$ & +23 \\
\hline - agricultural soils & 18,000 & 4,000 & $-14,000$ & -78 \\
\hline
\end{tabular}

a "other food products (imports)": all food imports except those already accounted for in "meat (net imports)"; direct imports by private consumers are not covered | b "other net imports of goods": all net imports of goods not already accounted for in other flows I c "other food products (exports)": all food exports except those already accounted for in "meat (net imports)" and "pig bones (exports)"

The first control mechanism was enacted by the authorities. These are responsible for ensuring short- and long-term social wellbeing. In practice, short-term, urgent problems are often prioritized, whereas long-term challenges are pushed aside. This can be observed in the conflict concerning the use of animal bones: while it is worth striving to recycle the P contained in animal bones as part of long-term resource management, human health was prioritized during the BSE crisis. This was also called for by the media, which mainly argued from a short- and medium-term point of view. As a result, the authorities implemented measures to ensure consumer safety by preventing the possible transfer of BSE pathogens. The measures were taken based on the precautionary principle declared in the Swiss Environmental Protection Law (USG 1983, art. 1 par. 2), as no conclusive evidence of the link between variant Creutzfeldt-Jakob Disease and BSE existed (Campbell and Sato 2009, Kewell and Beck 2008).

The second control mechanism was exerted by the population. The media acted as an amplifier, revealing the BSE problem to society (see Volger 2001). For public acceptance, potential risks of a solution play an important role. Accordingly, the products associated with BSE lost acceptance. Either they were no longer purchased by consumers, or they were removed from circulation by intermediary trade organizations or processing companies. The latter mainly occurred to head off image problems and resulting revenue losses. Following the developments described, breaking the material cycle was a logical consequence from a societal point of view.

As a consequence from both control mechanisms (ban and lack of demand), the financial and economic case for recycling bones also lost importance. Moreover, the use of "risk material" during and after the BSE crisis could even have led to economic losses as a result of the necessary destruction of infected livestock or claims for sickness compensation. Besides, possible production failures, restrictions on trade or reputational damage could have caused financial losses on the part of the affected producers and butchers. However, the control mechanisms themselves also brought direct negative economic consequences to bear. The costs of the general ban on MBM in animal feed and on fat extraction were estimated to 36 million CHF (approximately 27 million EUR) per year already, due to the disposal of meat and bone waste that had, until then, been used. In the beginning, the national government, and thus the taxpayer, bore 75 percent of these costs (Swiss Federal Council 2001).

\section{Export instead of Recycling}

The authorities did not consider re-allowing the reuse of bones, due to the potential danger of contamination during sorting for recycling and the subjective risk assessment imposed by end consumers and middlemen. However, not all body parts of an animal infected with BSE are dangerous. With regard to bones, only the skull and the spinal column are likely to be contagious, as they could have been contaminated by the brain or the spinal cord. Besides, only ruminants could possibly be affected. Accordingly, waste from pigs has never been considered to be risky material. In Switzerland, as in the EU, animal by-products are divided into three risk categories (Regulation [EC] 1774/2002), from the highest risk category 1 (animal carcasses, BSE cases, specific risk material, etc.) to the lowest category 3 (harmless goods). Disposing of the perishable bones in strict compliance with the risk categories requires additional logistical expenditures, including deliveries to different companies instead of just one. Before 2002, for cost reasons, the various waste producers delivered all bones, mixed together, to one recycling company. As a result, all material had to be classified as risk category 1 , although 90 percent of the bones in question were harmless in terms of BSE risks (category 3). Under these circumstances, a safe recycling alternative for the potentially infectious material, one that would be acceptable to the authorities, could not be found.

Thus, facing the BSE crisis, Geistlich Agrasana AG decided to implement a "material flow separation strategy" instead of continuing to process all bone categories together. As from October 2004, they only accepted category 3 bones, as recycling of these bones is permitted in Switzerland (VTNP 2004, art. 15). Initially, the great majority of bone waste producers from the meat industry accepted the additional costs for material separation, meaning that the amounts of bone waste delivered to Geistlich Agrasana AG decreased only slightly. In doing so, still 80 to 90 percent of the phosphorus contained in bones could be returned to the nutrient cycle, even though most of the bone meal produced had 


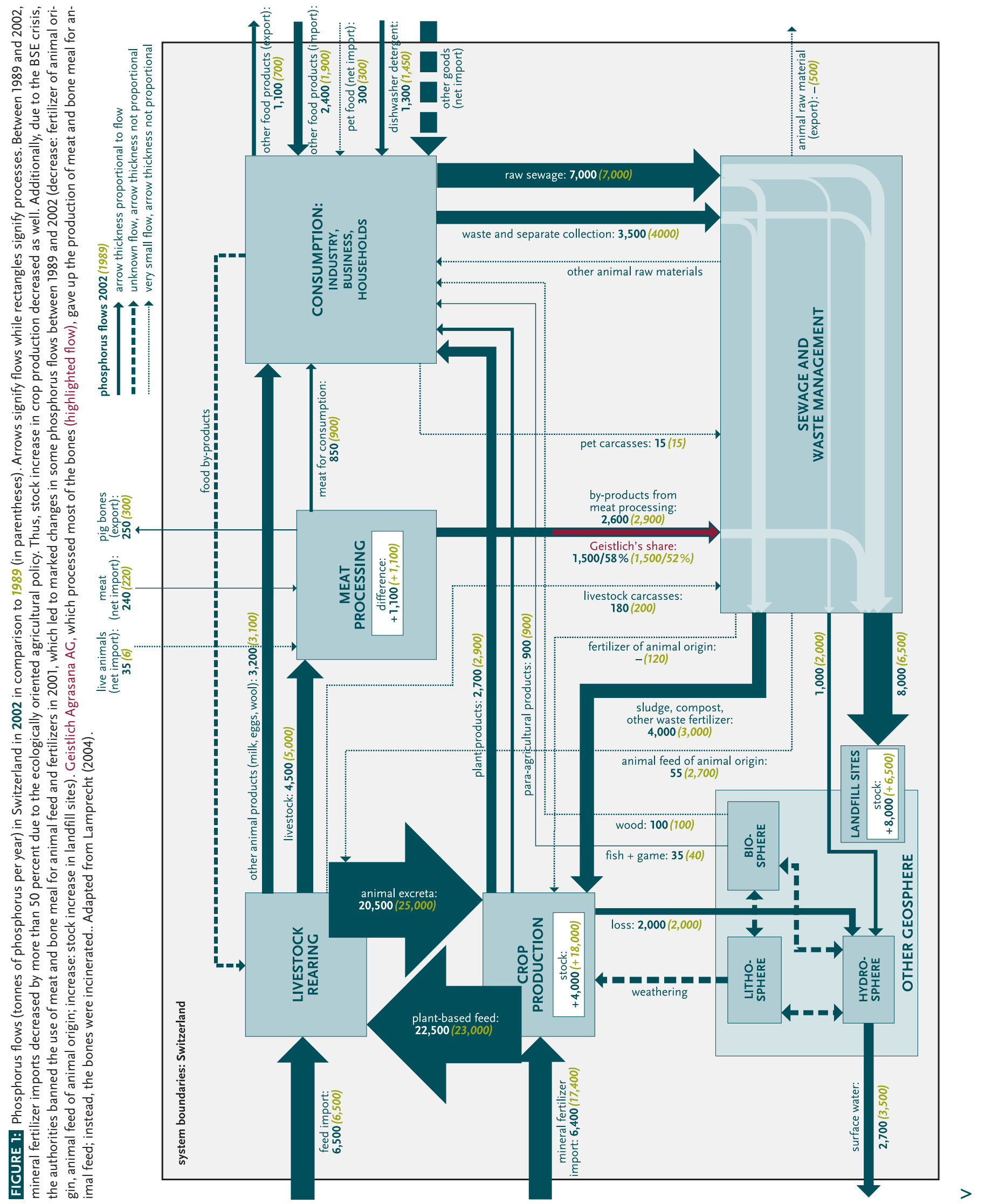


to be exported. ${ }^{5}$ However, different (market) developments forced Geistlich Agrasana AG to abandon the bone processing business in 2006, its traditional field of activity (started 155 years before). According to a newspaper article, among other things, large retailers' behavior contributed to this development: The latter refused to accept "fat produced from bones as an element of their animals' feed” (Vögeli 2006, translation by the authors). In general, the export of animal carcasses is banned for hygienic reasons. However, risk category 3 pig bones were increasingly declared legally as food, meaning they were no longer affected by the export ban. In this way, it was possible to export these bones unprocessed to the European Union, where they were subsequently transformed into gelatin and other products, which is presumably the most lucrative means of bone waste disposal.

\section{A Way out of the Dilemma?}

The material flow analysis shows that the bone disposal dilemma had a clear impact on Switzerland's phosphorus cycle. In 2006, a substantial proportion of the animal by-products generated in Switzerland was exported (about 71,000 t, which equals about 1,500 t P; Binder 2009), mainly to be further processed (e. g., as fertilizer and gelatin) in other countries. Thus, the phosphorus in question left the system boundaries set for our MFA, though a substantial share returned to the material cycle outside Switzerland. A domestic solution did not appear feasible for economic and acceptance reasons and because of strict regulations in the handling of such fertilizers ${ }^{6}$. Whether this practice made sense in the context of sustainable development cannot be assessed without further thorough analysis. However, we should critically regard the fact that, domestically, health precautions were accorded more weight than closing the P cycle, whereas risks were weighted differently outside the country. In such cases, it would be logical to conduct an international assessment and to subsequently harmonize regulations and practices, as is already the case in many areas of waste management.

From our analysis, we conclude that as long as the quality and safety of products made from secondary raw materials was not guaranteed, it was reasonable, as a precaution, to resign recycling. However, in the long run, and in accordance with the precautionary principle, one should try to find integral and safe, as well as economically and ecologically purposeful, solutions to close the material cycle. Because of the essential role of $\mathrm{P}$, and in terms of intergenerational fairness, the dependence of the anthropogenic $P$ balance on geogenic $P$ should be reduced to the minimum required as soon as possible. While at least some improvements in this direction have been made in Swiss agriculture in recent

5 National demand for bone meal fertilizer was not high enough. This was because of the oversupply of $\mathrm{P}$ for the soil and labeling programs used by major distributors who still refused to accept animal-origin fertilizers.

6 Stated by Egon Biedermann, Geistlich Agrasana AG, and Urs Zimmerli, Federal Department for Veterinary Affairs, on March 7, 2007.

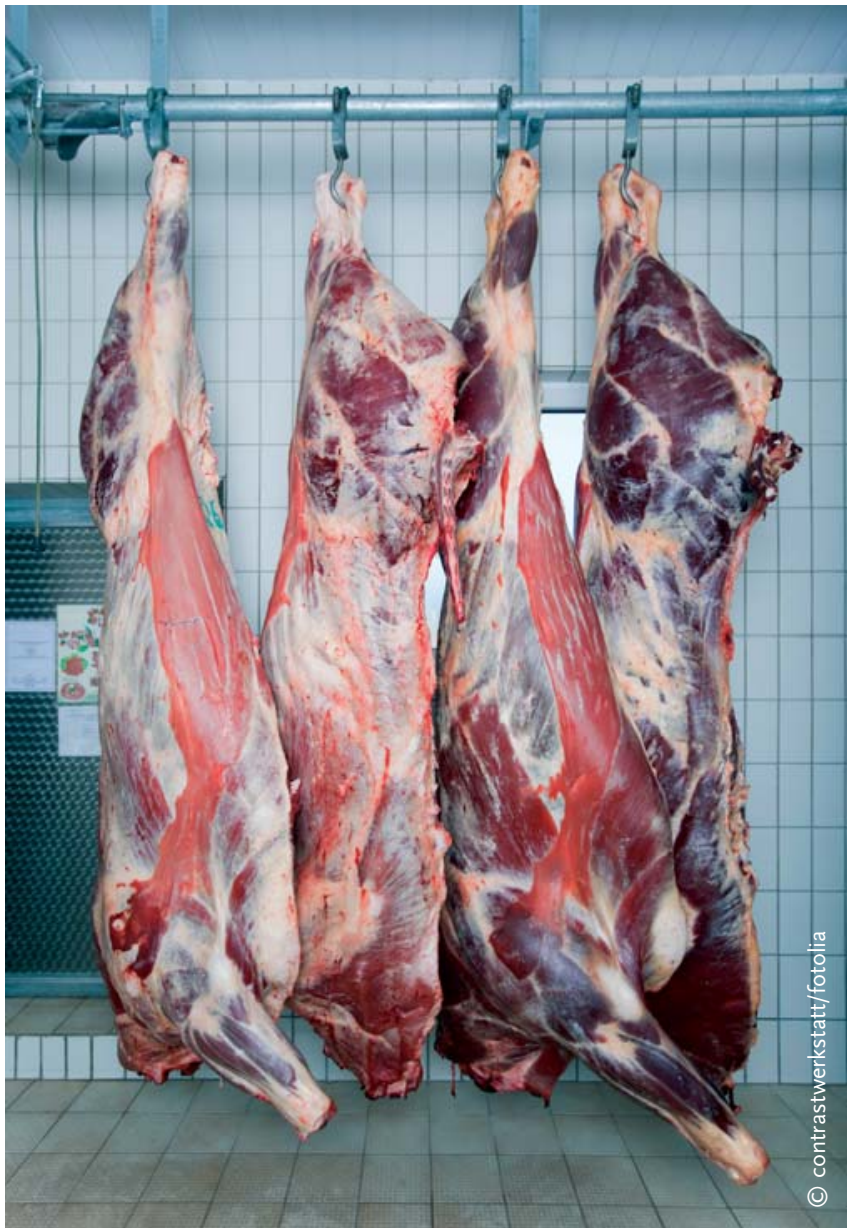

FIGURE 2: 65 percent of slaughtered animals are animal by-products. In Switzerland, in 2002, such by-products, which were mostly incinerated after BSE, contained 2,600 tonnes of phosphorus. The loss from the phosphorus cycle equalled 15 percent of phosphorus imports.

years, sewage and waste management have been moving backwards. In terms of quantity, our analysis identified sewage sludge as a greater potential source for recovering phosphorus than animal by-products (see also Binder et al. 2009). Sludge-based fertilizing would both allow the conservation of nutrient reserves and reduce disposal costs (Herter and Külling 2003). However, the use of sludge as fertilizer has been controversial for a long time because it contains harmful substances and organisms. Although sludge quality has improved in recent years concerning the heavy metal content (Stadelmann et al. 2002), the acceptance of sludge has dropped. As the issue of hard-to-degrade substances (micropollutants; Stadelmann et al. 2002, see also Schluep et al. 2006) had become an ever more important part of the debate on the use of sludge, the authorities were forced to act. Although a risk analysis by the Swiss Research Institute for Agriculture and Farming (FAL 2001) found no urgent need for action, the authorities attached more importance to soil conservation and food safety than to the resource aspect. For that reason, in 2003, a precautionary ban on the use of sludge as fertilizer was imposed that grad- 
ually came into force until 2008. Even before the ban, only around 40 percent of sewage sludge was used as fertilizer (Stadelmann et al. 2002); the remainder was dried and burned. The bottom ash was landfilled, its phosphorus being lost to the nutrient cycle. In 2006, only 600 t P/a of Swiss sludge was used in agriculture (Binder et al. 2009).

Like other countries, Switzerland is endeavoring to develop new waste management solutions in order to retain phosphorus in the cycle. The Canton of Zurich agreed, for instance, to a forward-looking and innovative guideline already in May 2007, which states: "With a view to achieving sustainable resource management, the planning of future methods of disposal, especially by building new facilities, should be arranged so that (in the future) it is possible to recover the reusable material phosphorus" 7 . This made the objective of closing the cycle official. However, how and when phosphorus is recovered was left open, permitting flexible solutions in keeping with the actual conditions (techno- to upstream incineration at high temperatures, incurs neither the risk of disseminating prions nor of contaminating products with harmful organic materials (see, e. g., Vogel et al. 2009). ${ }^{9}$ Other solutions in the case of sludge are the upstream recovery of phosphorus from sewage (Shu et al. 2005) or direct separation of urine in special toilets (Lienert and Larsen 2007). ${ }^{10}$ The issue of handling sludge demonstrates that totalling costs and benefits could be necessary, taking into account different considerations. Even after solving the hygiene problem by the new technologies, new dilemmas could arise: the recovery of phosphorus could, for instance, to a certain extent conflict with the goal of generating energy from sludge (Rulkens 2008).

It is to be expected that in waste management situations will consistently occur in which different objectives conflict with each other. When considering complex questions related to sustainable development, such a weighing up of conflicting objectives is often inevitable. Consequently, the definition of sustainability

\section{Reaching consensus on redesigning the material cycle is made difficult by the fact that objective risk assessments are often encumbered by significant uncertainties, subjective risk assessments give widely varying results, and goal conflicts are often inevitable. In this context, we must ask to what extent material cycles should be adapted to our safety and our consumption requirements. At the same time, however, the question also has to be posed in reverse: to what extent must our requirements be adjusted to what is necessary and feasible?}

logical, economic and social). According to the goals of the Federal Office of the Environment, throughout Switzerland, after a transition period of several years separate processing of MBM and sewage sludge shall be mandatory and $\mathrm{P}$ shall be recovered as far as possible to improve plant availability (Schenk 2011).

Incinerating animal bones and sewage sludge separately, with the concomitant recovery of $\mathrm{P}$ from the ashes, is a promising disposal solution that could resolve the dilemma of weighing health precautions against closing the cycle. This technology requires separate incineration in a suitable facility. ${ }^{8}$ Such a facility would be subject to a certain amortization period. In light of the rapidly changing regulations concerning the permitted uses of bone meal and sludge, the investment risk for such a facility is hard to assess; this is often an obstacle to investment in innovative technologies (Spoerri et al. 2010). As an answer to this, Switzerland considers subsidies for such facilities (Schenk 2011). Additionally, the phosphorus contained in the ashes shows limited plant availability and must be converted to a more readily soluble form. Recovering P from the ashes is technically feasible and, thanks is most often accompanied by "an inextricable combination of value judgments, world views and consensual knowledge” (Lélé and Norgaard 1996, p. 355). Based on the agent analysis, we were able to show that in cases where there are complex problems in weighing different objectives, an integrated analysis of material, economic, and social aspects is crucial. Our analysis can be understood as a first step of such a process, which contributes, on the basis of a retrospective analysis, to a better understanding of dis-

7 Stated by Franz Adam, head of the Waste and Dangerous Waste section of the Canton of Zurich's Environmental Protection Agency (AWEL, Amt für Abfall, Wasser, Energie und Luft), on June 4, 2007.

8 In order to prevent mixing with other waste materials or impure fuels (coal) as, otherwise, heavy metals would once again be part of the incineration process.

9 A comprehensive review of the "environmental and biosecurity characteristics of livestock carcass disposal methods", also including innovative methods we cannot mention here, can be found in Gwyther et al. (2011)

10 A comparative assessment of different approaches to phosphorus recovery from sewage and sludge can be found in Lundin et al. (2004), for instance. 
posal dilemmas. In order to make this assessment comprehensive, its analysis should, for example, be supplemented with finance flows and value creation aspects (see, e. g., Lang et al. 2006), other economic considerations (Binder 2007), systemic aspects such as buffer capacity and resilience (see, e. g., Lang et al. 2007), or an in-depth assessment of interests and the decision-making logic of the actors involved (Scholz 2011).

The agents' different interests and time dimensions considered indicate that in order to find a robust solution, a consensus building process is necessary. This should ideally be realized in a transdisciplinary process that discloses both the actors' interests and the uncertainties of scientific data. The goal should be to jointly define strategies that also comprise a comprehensive assessment of the different options.

In many cases, approaches aiming at sustainable development cannot be limited to technical solutions. In order to reach consensus on redesigning the material cycle, intensive co-operation is required between all involved parties. This is made difficult by the fact that objective risk assessments and weighing processes are often encumbered by significant uncertainties (see Smieszek 2006, Renn 1999), that subjective risk assessments give widely varying results, and that goal conflicts are often inevitable. In this context, we must ask to what extent material cycles should be adapted to our safety and our consumption requirements. At the same time, however, the question also has to be posed in reverse: to what extent must our requirements be adjusted to what is necessary and feasible?

The authors would like to thank Hans-Peter Fahrni, Roman Müller and Andreas Geistlich, Timo Smieszek and Stefan Zemp, as well as four anonymous reviewers for their critical and constructive comments and the improvements they suggested. Additionally, we would like to thank Konrad Schleiss for the expert input provided and Heather Murray for editing the text. Finally, our thanks to Geistlich Pharma AG for supporting this project financially and to the Canton of Zurich's Environmental Protection Agency (Amt für Abfall, Wasser, Energie und Luft, AWEL) for their years of support for research in the field of waste and resource management.

\section{References}

Ayres, R.U. 2007. On the practical limits to substitution. Ecological Economics 61: 115-128.

Baccini, P., H. P. Bader. 1996. Regionaler Stoffhaushalt: Erfassung, Bewertung und Steuerung. Heidelberg: Spektrum.

Binder, C. R. 2007. From material flow analysis to material flow management Part II: The role of structural agent analysis. Journal of Cleaner Production 15/17: 1605-1617.

Binder, C. R., L. de Baan, P. Mouron, D. Wittmer. 2009. Phosphorflüsse in der Schweiz: Stand, Risiken und Handlungsoptionen. Bern: Bundesamt für Umwelt. www.bafu.admin.ch/publikationen/publikation/01516/index.html?lang=de (accessed March 2, 2011).

Binder, C. R., C. Hofer, A. Wiek, R.W. Scholz. 2004. Transition towards improved regional wood flows by integrating material flux analysis: The case of Appenzell Ausserrhoden, Switzerland. Ecological Economics 49: 1-17.

Brunner, P. H., H. Rechberger. 2004. Practical handbook of material flow analysis: Advanced methods in resource and waste management. Boca Raton, FL: Lewis.

Campbell, R., H. Sato. 2009. Policy and politics of BSE in the United States. In: Management of health risks from environment and food. Edited by H. Sato. Dordrecht: Springer. 317-338.
Cordell, D., J. O. Drangert, S. White. 2009. The story of phosphorus: Global food security and food for thought. Clobal Environmental Change 19/2: 292-305.

DLG (Deutsche Landwirtschafts-Gesellschaft). 1973. DLG-Futterwerttabellen. Mineralstoffgehalte in Futtermitteln. $2^{\text {nd }}$ edition. Frankfurt on the Main: DLG DüBV (Düngerbuch-Verordnung). 2001. Verordnung des EVD vom 28. Februar 2001 über das Inverkehrbringen von Düngern. SR (Systematische Sammlung des Bundesrechts) 916.171.1.

DüV (Dünger-Verordnung). 2001. Verordnung vom 10. Januar 2001 über das Inverkehrbringen von Düngern. SR (Systematische Sammlung des Bundesrechts) 916.171.

Elmadfa, I. 1988/1989. Die große GU Nährwert-Tabelle. Gießen: Gräfe und Unzer. FAL (Swiss Research Institute for Agriculture and Farming). 2001. Risikoanalyse zur Abfalldüngerverwertung in der Landwirtschaft. Teil 1: Grobbeurteilung. Zurich: FAL.

FOAG (Federal Office for Agriculture). 2002. Agrarbericht 2002 - Ökologie. Bern: FOAG. www.blw.admin.ch/old/agrarbericht2/d/oekologie/ oekologie.htm (accessed December 18, 2008).

FOEN (Federal Office for the Environment). 2003. Erhebung der Kehrichtzusammensetzung 2001/02. Schriftenreihe Umwelt 356. Berne: FOEN.

Gwyther, C. L., A. P. Williams, P. N. Golyshin, G. Edwards-Jones, D. L. Jones. 2011. The environmental and biosecurity characteristics of livestock carcass disposal methods: A review. Waste Management 31/4: 767-778.

Heffer, P., M. Prud'homme, B. Muirheid, K. F. Isherwood. 2006. Phosphorus fertilisation: Issues and outlook. In: Proceedings 586 of the International Fertiliser Society Conference in Cambridge, United Kingdom, 14 December 2006. York, UK: International Fertiliser Society.

Herter, U., D. Külling. 2003. Multikriterienanalyse zur Bewertung von Risiken und Nutzen bei der Düngeranwendung. In: Risikoabschätzung zur landwirtschaftlichen Abfalldüngerverwertung. Edited by U. Herter et al. Zurich: FAL (Swiss Research Institute for Agriculture and Farming). 103-110.

IFADATA. 2011. Statistics of the International Industry Fertilizer Association (IFA). www.fertilizer.org/ifa/ifadata/search (accessed April 14, 2011).

Jeng, A. S., T. K. Haraldsen, A. Gronlund, P. A. Pedersen. 2006. Meat and bone meal as nitrogen and phosphorus fertilizer to cereals and rye grass. Nutrient Cycling in Agroecosystems 76/2-3: 183-191.

Jönsson, H. 2002. Urine separating sewage systems - Environmental effects and resource usage. Water Science Q Technology 46/6-7: 333-340.

Kewell, B., M. Beck. 2008. The shifting sands of uncertainty: Risk construction and BSE/vCJD. Health, Risk o Society 10/2: 133-148.

Lamprecht, H. 2004. Beitrag von Knochen am Phosphorhaushalt der Schweiz und Phosphorrecycling unter dem Einfluss der BSE-Problematik. Master thesis, ETH Zurich.

Lang, D. J., C. R. Binder, M. Stauffacher, C. Ziegler, K. Schleiss, R. W. Scholz. 2006. Material and money flows as a means for industry analysis of recycling schemes - A case study of regional bio-waste management. Resources, Conservation and Recycling 49/2: 159-190.

Lang, D. J., R. W. Scholz, C. R. Binder, A. Wiek, B. Stäubli. 2007. Sustainability potential analysis (SPA) of landfills - A systemic approach: Theoretical considerations. Journal of Cleaner Production 15: 1628-1638.

Lélé, S., R. B. Norgaard. 1996. Sustainability and the scientist's burden. Conservation Biology 10: 354-365.

Lienert, J., T. A. Larsen. 2007. Soft paths in wastewater management The pros and cons of urine source separation. GAIA 16/4: 280-288.

Liu, Y., G. Villalba, R. U. Ayres, H. Schroder. 2008. Global phosphorus flows and environmental impacts from a consumption perspective. Journal of Industrial Ecology 12/2: 229-247.

Lundin, M., M. Olofsson, G.J. Pettersson, H. Zetterlund. 2004. Environmental and economic assessment of sewage sludge handling options. Resources, Conservation and Recycling 41/4: 255-278.

Notholt, A. J. G., R. P. Sheldon, D. F. Davidson (Eds.). 1989. Phosphate deposits of the world. Volume 2: Phosphate rock resources. Cambridge, UK: Cambridge University Press.

Patyk, A., G. Reinhardt. 1997. Düngemittel - Energie- und Stoffstrombilanzen. Braunschweig: Vieweg.

Regulation (EC) 1774/2002. Regulation (EC) 1774/2002 of the European Parliament and of the Council of 3 October 2002 laying down health rules concerning animal by-products not intended for human consumption. Official Journal L 273, 10 October 2002.1-95. 
Renn, O. 1999. A model for an analytic-deliberative process in risk management. Environmental Science o Technology 33: 3049-3055.

Rulkens, W. 2008. Sewage sludge as a biomass resource for the production of energy: Overview and assessment of the various options. Energy Q Fuels 22: 9-15.

Schenk, K. 2011. TVA-Revision - Normkonzept. Berne: FOEN (Federal Office for the Environment).

Scheunert, A., A. Trautman. 1987. Lehrbuch der Veterinär-Physiologie. $7^{\text {th }}$ edition. Berlin: Paul Parey.

Schluep, M., M. Thomann, A. Häner, R. Gälli. 2006. Organische Mikroverunreinigungen und Nährstoffhaushalt. Eine Standortbestimmung für die Siedlungswasserwirtschaft. Berne: Bundesamt für Umwelt.

Schnug, E., S. Kratz, K. Stöven, F. Godlinski. 2011. Die Nutzung von Schlachtnebenprodukten als Dünger. Paper presented at the conference Die (Wieder-) Nutzung von Schlachtnebenprodukten at the Stiftung Tierärztliche Hochschule Hannover. Hannover, February 4.

Scholz, R. W. 2011. Environmental literacy in science and society: From knowledge to decisions. Cambridge, UK: Cambridge University Press.

Schröder, J.J., D. Cordell, A. L. Smit, A. Rosemarin. 2010. Sustainable use of phosphorus. Wageningen, NL: Plant Research International, Wageningen University and Research Centre.

Schuh, H. 2005. Ohne Phosphat läuft nichts. Die Zeit 23, June 2, 2005.

Shu, L., P. Schneider, V. Jegatheesan, J. Johnson. 2005. An economic evaluation of phosphorus recovery as struvite from digester supernatant. Bioresource Technology 97/17: 2211-2216.

Sims, J.T., P. A. Vadas. 2005. Phosphorus in soils. In: Encyclopedia of soils in the environment. Edited by D. Hillel. Amsterdam: Elsevier. 202-210.

Smieszek, T. 2006. Unsicherheit, Werthaltung und Handlungsblockaden. GAIA 15/4: 251-254

Smil, V. 2000. Phosphorus in the environment: Natural flows and human interferences. Annual Review of Energy and the Environment 25: 53-88.

Spiess, E., E. Plüss. 1999. Nährstoffbilanz der schweizerischen Landwirtschaft für die Jahre 1975 bis 1995. Zurich: FAL (Swiss Research Institute for Agriculture and Farming).

Spoerri, A., D. J. Lang, B. Stäubli, R. W. Scholz. 2010. Technological change in Swiss thermal waste treatment: An expert-based socio-technical analysis. Waste Management 30: 1382-1394.

Stadelmann, F.X., D. Külling, U. Herter. 2002. Klärschlamm: Dünger oder Abfall? EAWAG News 53: 9-11.

Swiss Federal Council. 2001. Antwort des Bundesrates zur Motion 00.3627 Tiermehlverbot Mehrkosten, eingereicht von Bigger Elmar am 28.11.2000 im Nationalrat.

Swissveg. 2003. Schweizer Gemüse. Was wächst wo? Der Schweizer Gemüsegarten. Bern: Swissveg. www.swissveg.com/de/was-wachst-wo/welcome.htm (accessed December 8, 2003).

Syers, J. K., A. E. Johnston, D. Curtin. 2008. Efficiency of soil and fertilizer phosphorus use. FAO Fertilizer and Plant Nutrition Bulletin 18. Rome: FAO (Food and Agriculture Organization of the United Nations).

USG (Umweltschutzgesetz). 1983. Bundesgesetz über den Umweltschutz (Umweltschutzgesetz, USG) vom 7. Oktober 1983 (Stand am 1. August 2010). SR (Systematische Sammlung des Bundesrechts) 814.01.

USGS (United States Geological Survey). 2010. Phosphate rock. In: Mineral commodity summaries, January 2010. Edited by USCS. http://minerals.usgs.gov/minerals/pubs/commodity/phosphate_rock/ mcs-2010-phosp.pdf (accessed May 26, 2011).

Vaccari, D. A., P. Strand. 2010. Extrapolation of potential phosphorus production into the future. Paper presented at the $9^{\text {th }}$ International Conference on EcoBalance. Tokyo, November 9-12.

Van Kauwenbergh, S. J. 2010. World phosphate rock. Reserves and resources. Muscle Shoals, AL: International Fertilizer Development Center (IFDC).

Vögeli, D. 2006. Keine Knochenverarbeitung mehr in Schlieren - Geistlich gibt Produktionszweig auf. Neue Zürcher Zeitung, November 15, 2006. 266.

Vogel, C., C. Adam, S. Wellendorf. 2009. Phosphorus recovery from sewage sludge ash and meat and bone meal by thermochemical treatment. In: Proceedings of R'09 Twin World Congress - Resource Management and Technology for Material and Energy Efficiency, 14.-16.09.2009, Davos, Switzerland. Edited by L. M. Hilty et al. Davos, Switzerland: EMPA. Volume 1. 1-6.

Volger, G. 2001. Risikoeinschätzung und Medien: Beispiel Rinderwahnsinn. Term paper, ETH Zurich.
VTNP (Verordnung über die Entsorgung von tierischen Nebenprodukten). 2004. Verordnung über die Entsorgung von tierischen Nebenprodukten (VTNP) vom 23. Juni 2004. SR (Systematische Sammlung des Bundesrechts) 916.441.22.

Wilsenach, J.A., M. Maurer, T. A. Larsen, M. C. M. van Loosdrecht. 2003. From waste treatment to integrated resource management. Water Science Q Technology 48/1: 1-9.

Wirz. 2002. Wirzkalender. Handbuch „Pflanzen und Tiere“. Lindau, $\mathrm{CH}$ : Landwirtschaftliche Beratungszentrale Lindau, Wirz-Verlag.

Würtenberger, L., T. Koellner, C. R. Binder. 2006. Virtual land use and agricultural trade: Estimating environmental and socio-economic impacts. Ecological Economics 57/4: 679-697.

Ylivainio, K., R. Uusitalo, E. Turtola. 2008. Meat bone meal and fox manure as P sources for ryegrass (Lolium multiflorum) grown on a limed soil. Nutrient Cycling in Agroecosystems 81/3: 267-278.

\section{Submitted January 5, 2009; revised version} accepted May 19, 2011

Heinz Lamprecht

Born 1972 in Weisslingen, Switzerland. From 1989 to 1995 agro-biology laboratory technician. From 1998 to 2004 studies in environmental sciences at the Swiss Federal Institute of Technology (ETH) Zurich; master's thesis on the contribution of bones to Switzerland's phosphorus balance. Research associate at ETH Zurich. Since 2005 consultant at BMC Engineering AG, working on efficiency engineering and chemical safety.

\section{Daniel J. Lang}

Born 1974 in Kenzingen, Germany. Studies in geo-ecology and environmental sciences. Doctorate at ETH Zurich. From 2006 to 2009 (senior) scientist at ETH Zurich. Since 2010 professor of transdisciplinary sustainability research; since October 2010 vice dean of the Faculty of Sustainability at Leuphana University Lüneburg, Germany. Research focus: transdisciplinarity, sustainability science, human-environment systems, future studies, systemic sustainability assessment, waste and resource management, urban and regional transitions.

Claudia R. Binder

Born 1966 in Montreal, Canada. Studies in biochemistry; doctorate and habilitation in environmental sciences at ETH Zurich. From 2006 to 2009 assistant professor for Social and Industrial Ecology at the Department of Geography, University of Zurich. Since 2009 professor

for Systems Sciences and head of the Institute for Systems Science, Innovation and Sustainability Research at the University of Graz, Austria. Research focus: sustainable development, human-environment systems, transdisciplinary sustainability assessment, sustainable regional development, resource management, value supply chains.

\section{Roland W. Scholz}

Born 1950 in Halle (Saale), Germany. Studies in mathematics; doctorate and habilitation in psychology. Since 1993

full professor of environmental sciences at the Natural and Social Science Interface at ETH Zurich. Further assignments at the University of Zurich and Stellenbosch

University, South Africa. Research focus: sustainable transformation of urban and regional processes, organizations and political decision-making, sustainability learning, resilient human-environment relationships. 